\title{
Expression of genes encoding cellulolytic enzymes in some Aspergillus species
}

\author{
M.A. Mahmoud ${ }^{1}$, M.R. Al-Othman ${ }^{2}$, A.R.M. Abd-El-Aziz ${ }^{2}$, H.A. Metwaly ${ }^{3}$ \\ and H.A. Mohamed ${ }^{1}$ \\ ${ }^{1}$ Plant Pathology Research Institute, Agricultural Research Center, \\ Giza, Egypt \\ ${ }^{2}$ Botany and Microbiology Department, College of Science, \\ King Saud University, Riyadh, Saudi Arabia \\ ${ }^{3}$ Central Laboratory of Organic agricultural, Agricultural Research Center, \\ Giza, Egypt \\ Corresponding author: M.A. Mahmoud \\ E-mail: m.a.mahmoud75@gmail.com
}

Genet. Mol. Res. 15 (4): gmr15048913

Received June 22, 2016

Accepted August 25, 2016

Published October 17, 2016

DOI http://dx.doi.org/10.4238/gmr15048913

Copyright $(2016$ The Authors. This is an open-access article distributed under the terms of the Creative Commons Attribution ShareAlike (CC BY-SA) 4.0 License.

\begin{abstract}
Fermentation is an important industrial process for microbial metabolite development and has wide applications in various fields. Aspergillus is the most important genus of fungi used for the production of microbial enzymes such as cellulase. The Aspergillus genome encodes various cellulolytic enzymes. In this study, we assayed the gene expression and cellulolytic enzyme production of three isolates: A. niger (KSU009), A. terreus (KC462061), and A. flavus (KSU014). Two fermentation systems, submerged fermentation and biofilm fermentation (BF), were used for this purpose. Gene expression analysis by RT-PCR showed that $c b h B$, exo, eglA, eglB, eglC, and $\beta$-actin genes were differentially expressed in the two fermentation systems for these three isolates during enzyme production. Furthermore,
\end{abstract}


the expression of all genes was found to be higher in the BF system. The six genes were not expressed in the isolates with no cellulolytic enzyme production. The isolates were identified by morphological and molecular methods, which were based on macroscopic characteristics and sequence analysis of ITS1, ITS2, and the 5.8S regions of rDNA.

Key words: Aspergillus spp; Cellulolytic enzyme genes; RT-PCR; Fermentation

\section{INTRODUCTION}

The global market for industrial enzymes was estimated to be $\$ 3.3$ billion in 2010 , and was expected to reach $\$ 4.4$ billion by 2015 (Parameswaran et al., 2013). The difficulty in producing cellulase at an industrial scale has been a bottleneck in the development of novel bioprocesses and production of biofuels and bioproducts from renewable sources (Sørensen et al., 2013). Cellulases can be classified into three major types, endoglucanases (EG) (EC 3.2.1.4), exoglucanases (EXG) (cellobiohydrolase) (EC 3.2.1.91), and $\beta$-glucosidases ( $\beta G$ ) (EC 3.2.1.21) (Rabinovich et al., 2002). Basic and applied research on cellulolytic enzymes has elucidated their roles in various industrial applications including food processing, animal feeds, fermentation, biofuels, agro-waste management, textiles, and the paper production (Kuhad et al., 2011).

Cellulase is primarily produced by microorganisms in nature (fungi, bacteria, and protozoa) (Watanabe and Tokuda, 2001). Various species of the Aspergillus genus (primarily Aspergillus niger) produce enzymes such as cellulase (Sridevi et al., 2015), lipase (Osuna et al., 2015), and estrase (Zhou et al., 2015). The four fermentation systems used for cellulose production are: submerged fermentation $(\mathrm{SmF})$, solid-state fermentation $(\mathrm{SSF})$, biofilm fermentation (BF), and surface-adhesion fermentation (Gutiérrez-Correa and Villena, 2003; Villena and Gutiérrez-Correa, 2006). SmF is based on the culture of microorganisms in a liquid nutrient broth, whereas other fermentation systems use a solid substrate surface for microorganism growth (Gutiérrez-Correa and Villena, 2003). In the BF system, filamentous fungi naturally attaches to the growth surface by cell adhesion or chemical bonding that induces changes in its physiology (Ghigo, 2003).

Genomes of several species of the Aspergillus genus often contain multiple cellulolytic enzyme genes that exhibit differential expression based on culture conditions and other factors (Ward et al., 2006). Genetic, transcriptomic, and proteomic studies have revealed that several genes and regulatory circuits are activated during enzyme production (Al-Sheikh et al., 2004).

Transcription patterns of cellulolytic enzymes have been examined via various molecular biological methodologies such as northern blotting (Marui et al., 2002), RTPCR (Mahmood et al., 2014), expressed sequence tag analysis (Todaka et al., 2010), DNA microarray analysis (Ogawa et al., 2013) and quantitative real-time PCR (Bak, 2015). The gene profiles of EGs (eglA, eglB, and eglC), EXGs ( $c b h A, c b h B$, and exo), and $\beta$ Gs ( $\beta$-actin) were found to vary in different fungi, especially in Trichoderma reesei and $A$. niger (Villena et al., 2009; Mahmood et al., 2014).

However, very few studies have examined the effect of fermentation systems on the expression of genes encoding cellulolytic enzymes. Thus, the aim of the current study was to

Genetics and Molecular Research 15 (4): gmr15048913 
assess differential gene expression of the Aspergillus spp (A.niger KSU009, Aspergillus terreus KC462061, and Aspergillus flavus KSU014) during enzyme production in two fermentation systems, BF and SmF.

\section{MATERIAL AND METHODS}

\section{Aspergillus isolates}

Six fungal isolates belonging to three different species of the Aspergillus genus were used in this study (Table 1). The six isolates were obtained from grains, seeds, and soil of agricultural crops. They were maintained under conditions as previously described (Mahmoud et al., 2014).

Table 1. Aspergillus isolates used in the study.

\begin{tabular}{l|l|l|l|l}
\hline No. & Accession & Origin & Source & Taxon \\
\hline 1 & KSU009 & Saudi Arabia & Corn & A. niger \\
\hline 2 & KC462061* & Saudi Arabia & Soil & A.terreus \\
\hline 3 & KSU014 & Saudi Arabia & Wheat & A. flavus \\
\hline *GenBank accession number.
\end{tabular}

\section{Identification of Aspergillus isolates}

Morphological and molecular identification of Aspergillus isolates were based on macroscopic characteristics as well as gene sequences of ITS1, ITS2, and the 5.8S regions of rDNA (Raper and Fennell, 1965; Gehlot et al., 2011). PCR was performed using the PCR T Personal Thermo Cycler (Biometra, Germany). The PCR products were sequenced using an automated ABI-Prism 377 DNA Sequencer (Applied Biosystems Inc., CA, USA). The MEGA 6.01 software was used to align the sequences of Aspergillus isolates with nucleotide sequences provided by the GenBank. The neighbor-joining method was used to create phylogenetic trees (Saitou and Nei, 1987). Identification at the species level was based on the percentage of ITS similarities (Higgins et al., 2007).

\section{Cellulolytic enzyme activity and fermentation system}

The two fermentation systems, BF and SmF, were used to measure cellulolytic enzyme activities. The three Aspergillus genus isolates, A. niger (KSU009), A. terreus (KC462061), and A. flavus (KSU014), were inoculated and cultured under both fermentation systems. Specifications and assays of the two fermentation systems are summarized in Table 2. The experiment was repeated for the same isolates, and mercury(II) sulfate was added at a concentration of $500 \mathrm{ppm}$ to stop enzymatic activities in the isolates.

\section{Extraction of total RNA and synthesis of cDNA}

Cultured Aspergillus isolates (100 mg) were extracted at 24, 48, 72, and $96 \mathrm{~h}$. The mycelial pellets were grounded in liquid nitrogen to isolate total RNA using the RNeasy plant mini kit (QIAGEN, Germany), according to manufacturer instructions. cDNA synthesis was 
carried out by reverse transcription using the ProtoScript First Strand cDNA Synthesis Kit (New England Biolabs, UK), according to the manufacturer instructions.

Table 2. Summary of fermentation systems used in the study.

\begin{tabular}{l|l|l}
\hline Item & Biofilm fermentation & Submerged fermentation \\
\hline inoculums formation & $2 \mathrm{~mL}$ spore suspension $\left(1 \times 10^{6}\right)$ & The same \\
\hline Culture medium & Duff media & The same \\
\hline Support media & Polyester cloth 100/1 & No support media \\
\hline Experimental steps & Incubation, shaker bath, washing and Incubation & The same \\
\hline Assays & Cellulase and xylanase were measured by one international unit (IU) of enzyme & The same \\
\hline References & (Mahmood et al., 2014, Villena et al., 2009) & \\
\hline
\end{tabular}

\section{Transcriptional analysis of selected cellulolytic genes}

The synthesized cDNA of each gene was amplified via PCR by using the combination of forward and reverse primers outlined in Table 3 (Mahmood et al., 2014). The reaction mixture contained $2.25 \mu \mathrm{L} 10 \mathrm{X}$ buffer, $1.8 \mu \mathrm{L}$ dNTP mix ( $5 \mathrm{mM}$ each), $0.5 \mu \mathrm{L}$ each forward and reverse primer $(10 \mu \mathrm{M}), 1 \mu \mathrm{L}$ Taq DNA polymerase (New England BioLabs, UK), 2.25 $\mu \mathrm{L}$ cDNA sample, and $11.7 \mu \mathrm{L} \mathrm{dH}_{2} \mathrm{O}$. The amplification protocol was as follows: initial denaturation at $95^{\circ} \mathrm{C}(4 \mathrm{~min}) ; 40$ cycles of: $95^{\circ} \mathrm{C}(30 \mathrm{~s}), 55^{\circ} \mathrm{C}(30 \mathrm{~s}), 72^{\circ} \mathrm{C}(30 \mathrm{~s})$; final extension at $72^{\circ} \mathrm{C}(5 \mathrm{~min})$; hold at $4^{\circ} \mathrm{C}$. The PCR products were separated on a $1.5 \%$ agarose gel containing ethidium bromide, and were electrophoresed $(75 \mathrm{~V})$ and visualized using a gel documentation system (UVP).

Table 3. Primer list (adapted from Mahmood et al., 2014).

\begin{tabular}{|c|c|c|c|c|c|c|}
\hline Primer pair & Gene & Sequence (5'-3') & Amplified region & MW & Optimum AT $\left({ }^{\circ} \mathrm{C}\right)$ & RT-PCR product size (bp) \\
\hline cbhB-F & \multirow[t]{2}{*}{$\operatorname{cbh} B$} & GCAAGTGTACCCACTCACACA & \multirow[t]{4}{*}{ Celobiohydrolase } & 6344.2 & \multirow[t]{2}{*}{58} & \multirow[t]{2}{*}{587} \\
\hline cbhB-R & & AAGCGGTTGTACGTGCAAGA & & 6206.1 & & \\
\hline Exo-F & \multirow[t]{2}{*}{ Exo } & TGTGCTCTCGTTGCCCTCTTG & & 6346.2 & \multirow[t]{2}{*}{60} & \multirow[t]{2}{*}{598} \\
\hline Exo-R & & AGTGCATTGGCGCCTTCCTC & & 6060.0 & & \\
\hline eglA-F & \multirow[t]{2}{*}{ eglA } & TCCCCGTGTCACTTGCTATG & \multirow[t]{6}{*}{ Endoglucanase } & 60.35 .0 & \multirow[t]{2}{*}{58.5} & \multirow[t]{2}{*}{391} \\
\hline eglA-R & & CAGTTCATAGTCGCCGCTAGA & & 6406.2 & & \\
\hline eglB-F & \multirow[t]{2}{*}{$e g l B$} & ATCTCAACCAAGCAGCCATT & & 6030.0 & \multirow[t]{2}{*}{56.5} & \multirow[t]{2}{*}{470} \\
\hline eglB-R & & CCAGGATATCCAGCATACCC & & 6031.0 & & \\
\hline eglC-F & \multirow[t]{2}{*}{ eglC } & TGGTGTTACCGGTCTCTTCAAAACCGA & & 8250.4 & \multirow[t]{2}{*}{61.5} & \multirow[t]{2}{*}{515} \\
\hline eglC-R & & GCTATACCAGGGATAGACTTACACTGCA & & 8581.7 & & \\
\hline$\beta$-actin-F & \multirow[t]{2}{*}{$\beta$-actin } & AGCGTGGTATCCTCACGCTC & \multirow[t]{2}{*}{$3 \beta$-glucosidase gene } & 6069.0 & \multirow[t]{2}{*}{57.5} & \multirow[t]{2}{*}{625} \\
\hline$\beta$-actin-R & & CTTCATGATGGAGTTGAACG & & 6172.1 & & \\
\hline
\end{tabular}

\section{RESULTS}

\section{Identification of Aspergillus isolates}

\section{A. niger KSU009}

A phylogenetic tree was constructed (Figure 1A), which included eight isolates related to $A$. niger. Four isolates were found to be closely related to A. niger (KSU009). As shown by the phylogenetic tree, A. niger KU681408, A. niger KR296852, and A. niger JN587346 
belonged to the same clade. A. niger KSU009 was found to be very closely related to $A$. niger KU681408, with an ITS sequence similarity of $99.9 \%$.
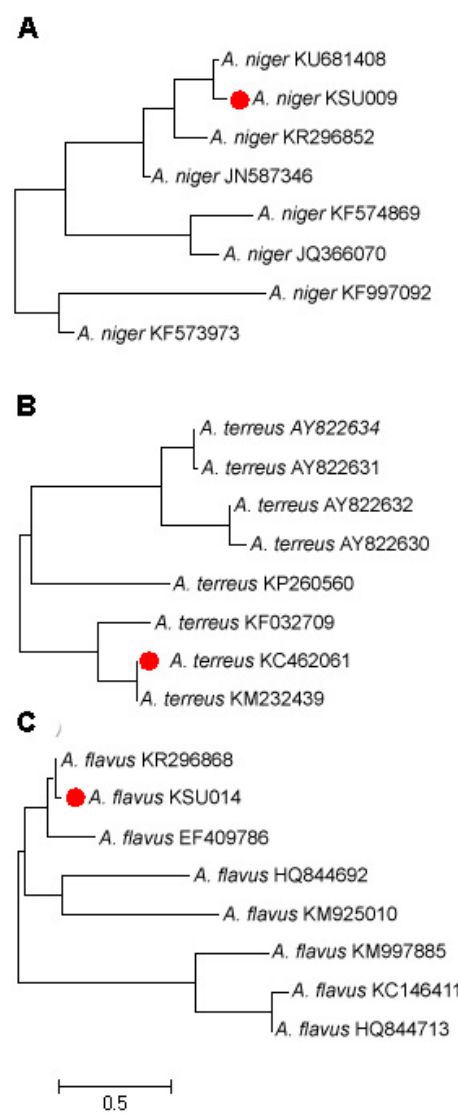

Figure 1. Phylogenetic tree of five Aspergillus species based on 5.8S and ITS sequences A. niger KSU009 (A); $A$. terreus KC462061 (B); A. flavus KSU014 (C).

\section{A. terreus KC462061}

The phylogenetic tree (Figure 1B) included eight isolates related to A. terreus KC462061. A. terreus KC462061 was found to be very closely related to A. terreus AY822634, with an ITS sequence similarity of $99.9 \%$.

\section{A. flavus KSU014}

The phylogenetic tree constructed (Figure 1C) consisted of eight isolates related to A. flavus. Three isolates were closely related to A. flavus KSU014. The phylogenetic tree indicated that A. flavus KSU014 was classified into the same clade as A. flavus KR296868 and A. flavus EF409786. A. flavus KSU014 was found to be very closely related to A. flavus KR296868, with an ITS sequence similarity of $99.9 \%$.

Genetics and Molecular Research 15 (4): gmr15048913 


\section{Cellulolytic enzyme activity}

\section{A. niger KSU009}

The effect of the two fermentation systems on enzyme production by A. niger KSU009 is represented in Figure 2. For the BF system, cellulase activity increased linearly with reaction time, up to a maximum of $72 \mathrm{~h}$, after which a decline in the activity was observed. Similar trend was also found for the $\mathrm{SmF}$ system. The effect of the BF and SmF systems on $\beta G$ production by A. niger KSU009 was also examined. The BF system led to higher enzyme yield as well as stronger correlation between enzymatic activity and incubation time, as compared to the SmF system. As expected, A. niger KSU009 treated with mercury (II) sulfate failed to produce any detectable amount of enzymes.

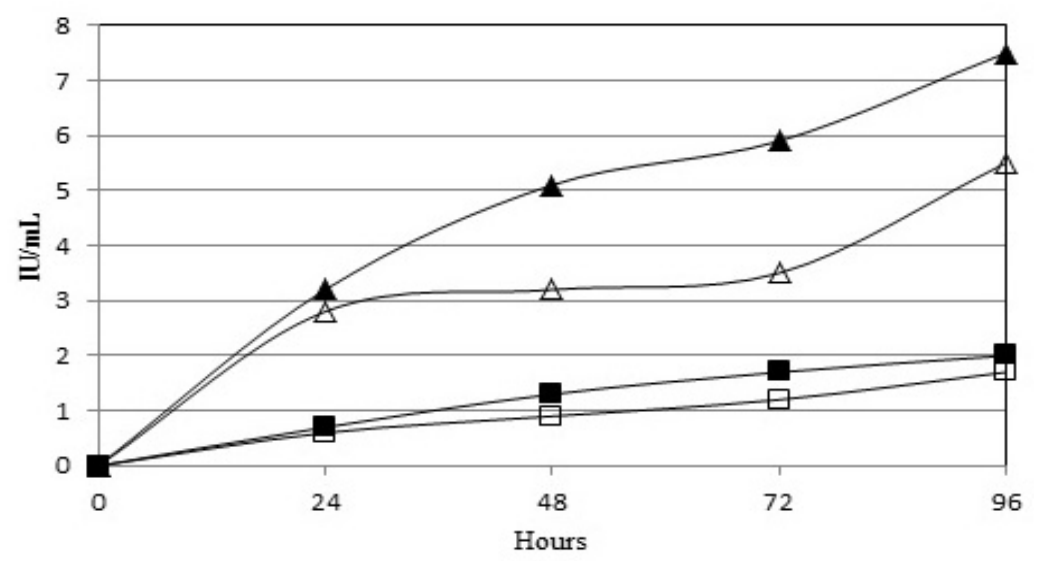

Figure 2. Activity of cellulase and $\beta \mathrm{G}$ in Aspergillus niger KSU009. Cellulase activity is represented by squares; $\beta \mathrm{G}$ activity is represented by triangles. A. niger KSU009 was grown in submerged fermentation (SmF, open symbols) and biofilm fermentation (BF, filled symbols).

\section{A. terreus KC462061}

The cellulase and $\beta \mathrm{G}$ activities were monitored for up to $96 \mathrm{~h}$ using the $\mathrm{BF}$ and $\mathrm{SmF}$ systems (Figure 3). A. terreus KC462061 produced cellulase under both BF and SmF systems, with higher yield found in the BF system as compared to that in the SmF system. $\beta \mathrm{G}$ activity in the BF and SmF systems showed steady increase with time during the incubation period. The activities of both the enzymes were higher under the BF system at the end of the incubation period. Mercury (II) sulfate treatment terminated enzyme production in A. terreus KC462061.

\section{A. flavus KSU014}

Production of cellulase and $\beta \mathrm{G}$ in the $\mathrm{BF}$ and $\mathrm{SmF}$ systems were also investigated in A. flavus KSU014 (Figure 4). The enzyme activity was monitored for $96 \mathrm{~h}$, and both the enzymes exhibited a gradual linear rise in enzyme production. The enzyme production was found to be higher under the BF system as compared to the $\mathrm{SmF}$ system. Mercury (II) sulfate treatment terminated enzyme production in A. flavus KSU014. 


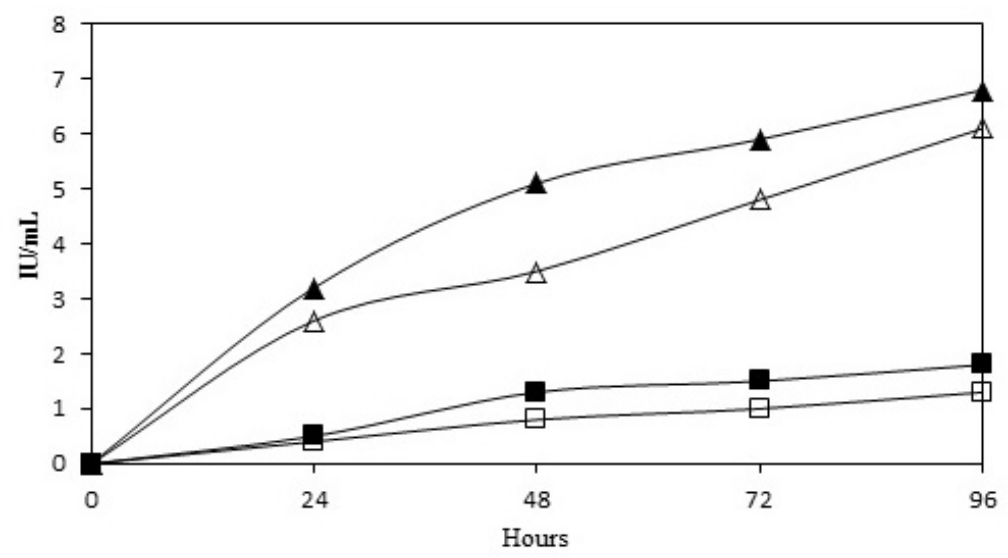

Figure 3. Activity of cellulase and $\beta \mathrm{G}$ in Aspergillus terreus KC46206. Cellulase activity is represented by squares; $\beta \mathrm{G}$ activity is represented by triangles. A. terreus KC46206 was grown in submerged fermentation (SmF, open symbols) and biofilm fermentation (BF, filled symbols).

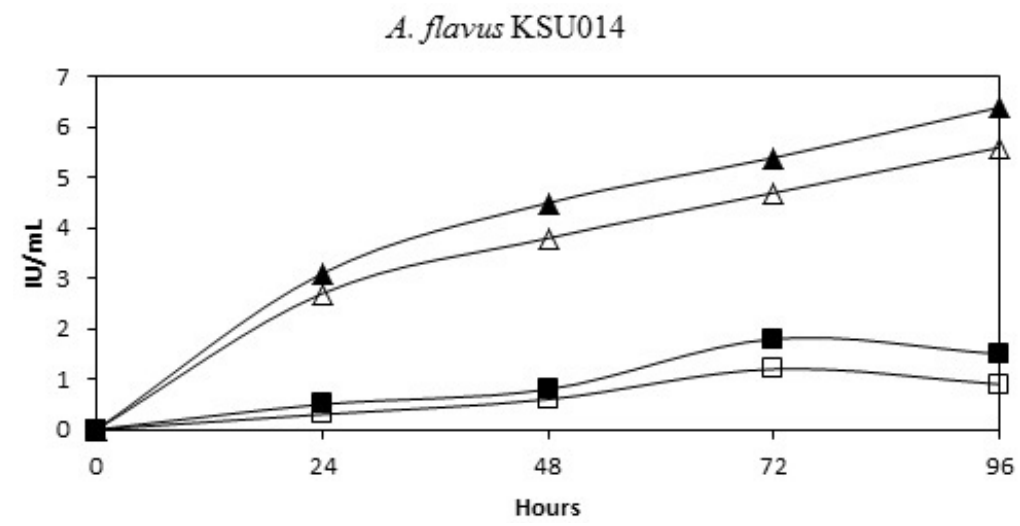

Figure 4. Activity of cellulase $\beta G$ in Aspergillus flavus KSU014. Cellulase activity is represented by squares; $\beta \mathrm{G}$ activity is represented by triangles. A. flavus KSU014 was grown in submerged fermentation (SmF, open symbols) and biofilm fermentation (BF, filled symbols).

\section{Transcriptional analysis of cellulolytic enzyme genes}

Transcriptional analysis of six cellulolytic enzyme genes $(c b h B$, exo, eglA, eglB, eglC, and $\beta$-actin) for the six isolates was performed via RT-PCR.

\section{A. niger KSU009}

Results showed differential expression of $A$. niger KSU009 enzyme genes under the $\mathrm{BF}$ and $\mathrm{SmF}$ systems (Figure 5). Following $24 \mathrm{~h}$ incubation, all the genes were weakly expressed under both the fermentation systems, with the exception of $c b h B$ and $e g l B$. Strong gene expression was observed in $\mathrm{BF}(\operatorname{Exo}, \operatorname{cbh} B$, and eglA) and $\mathrm{SmF}($ exo $)$ at $48 \mathrm{~h}$. At 72

Genetics and Molecular Research 15 (4): gmr15048913 
$\mathrm{h}$, higher transcriptional rate was observed for all the cellulolytic enzyme genes in the BF system, with the exception of eglA; the SmF system displayed medium transcriptional levels for all the tested genes. At $96 \mathrm{~h}$, gene expression in the BF system ranged from medium to high. In general, gene expression was higher in the BF system as compared to that in the SmF system. No gene amplification was observed when A. niger KSU009 was treated with mercury (II) sulfate.

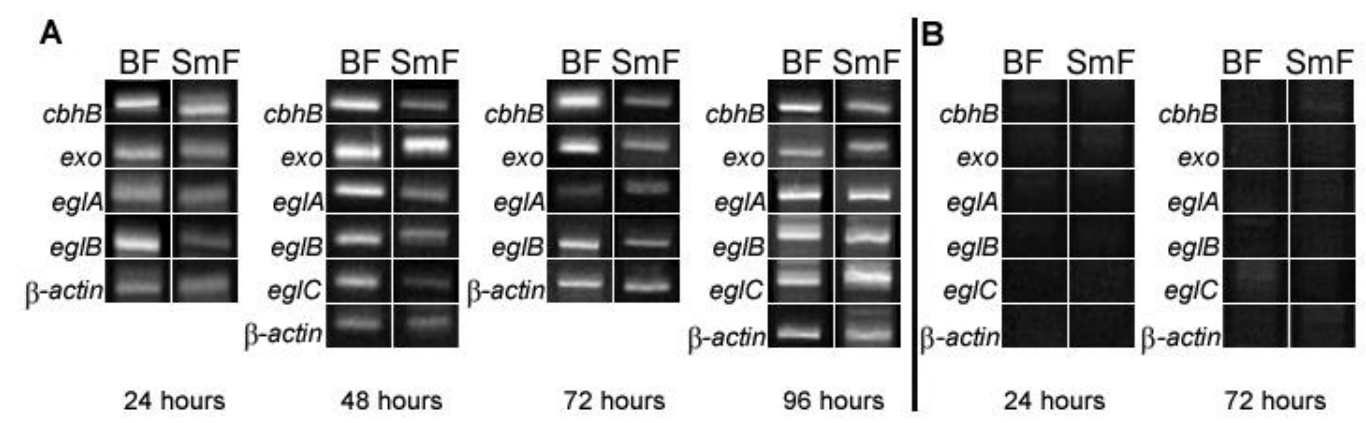

Figure 5. Expression of selected cellulolytic enzyme genes. A. Aspergillus niger KSU009 at 24, 48, 72, and 96 h, grown in BF and SmF systems; B. A. niger KSU009 treated with mercury at 24 and $72 \mathrm{~h}$, grown in BF and SmF systems.

\section{A. terreus KC462061}

Transcriptional analysis of six A. terreus KC462061 cellulolytic enzyme genes is shown for the $\mathrm{BF}$ and $\mathrm{SmF}$ systems (Figure 6). At 24 and $48 \mathrm{~h}$, all the enzyme genes, with the exception of $c b h B$ and eglA (48 h-BF), were weakly transcribed under both the fermentation systems. At $72 \mathrm{~h}$, all the genes under both the systems exhibited medium to high transcriptional levels. At $96 \mathrm{~h}$, gene expressions in the BF system were found to be higher as compared to that in the $\mathrm{SmF}$ system. The transcription was terminated with mercury treatment.

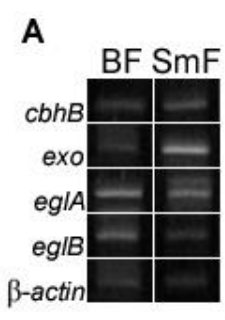

24 hours

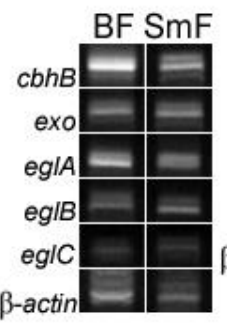

48 hours

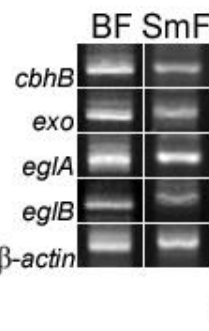

72 hours
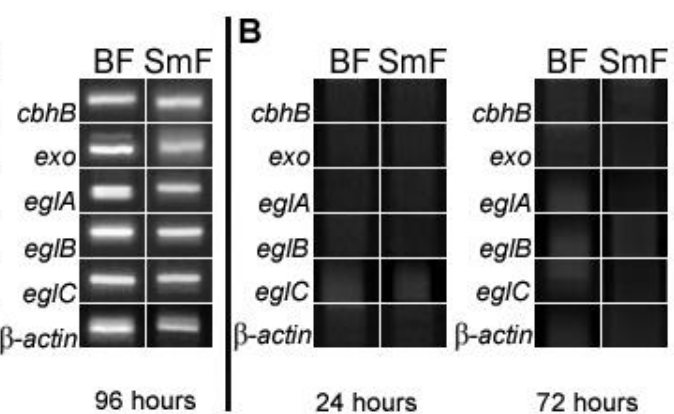

Figure 6. Expression of selected cellulolytic enzyme genes. A. Aspergillus terreus KC462061 at 24, 48, 72, and $96 \mathrm{~h}$, grown in $\mathrm{BF}$ and $\mathrm{SmF}$ systems; B. A. terreus $\mathrm{KC} 462061$ treated with mercury at 24 and $72 \mathrm{~h}$, grown in $\mathrm{BF}$ and $\mathrm{SmF}$ systems. 


\section{A. flavus KSU014}

Expression levels of the six cellulolytic enzyme genes were assessed by RT-PCR under the BF and $\mathrm{SmF}$ systems (Figure 7). At 24 and $48 \mathrm{~h}$, all the genes were weakly expressed under both the fermentation systems. At 72 and $96 \mathrm{~h}$, higher gene expression was observed under the BF system, as compared to that under the SmF system. Similarly, no gene transcription was observed with mercury treatment.

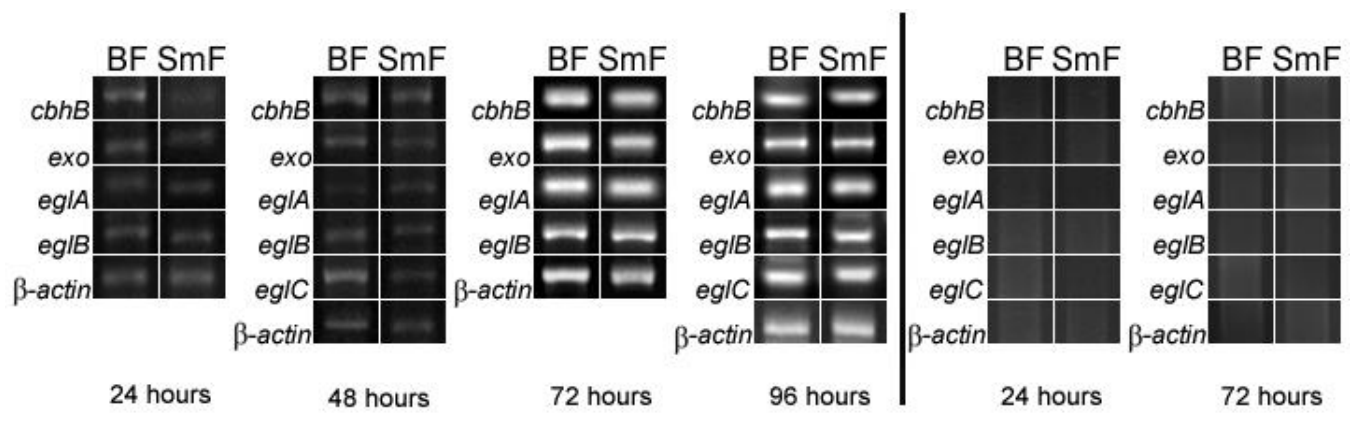

Figure 7. Expression of selected cellulolytic enzyme genes. A. Aspergillus flavus KSU014 at 24, 48, 72, and 96 h, grown in BF and SmF systems; B. A. flavus KSU014treated with mercury at 24 and $72 \mathrm{~h}$, grown in BF and SmF systems.

\section{DISCUSSION}

Microbial cellulolytic enzyme production under both SmF and SSF systems have been assessed in recent studies (Renge et al., 2012). A. niger can be successfully cultured under both SmF and SSF systems for cellulase production. Cellulase production by SSF system was found to be 3- to 14-fold higher as compared to that by SmF. Factors that affect the production of microbial enzymes include inoculum size, carbon and nitrogen sources, as well as physicochemical conditions such as temperature, $\mathrm{pH}$, and incubation period (Shivanna and Venkateswaran, 2014; Reddy et al., 2015).

Furthermore, cellulase activity of $A$. flavus AT-2 cultured under the SSF system was $42.69 \%$, which was higher as compared to that obtained under the SmF system. It was proposed that optimal conditions for maximum cellulase production included a fungal inoculum dose of $5 \%$, an incubation period of 5 days, a temperature of $30^{\circ} \mathrm{C}$, a $\mathrm{pH}$ of 4.8 , and usage of rice straw as the substrate (Dutt and Kumar, 2014). However, the proposed optimal conditions differed between studies due to different sources of isolates (water, soil, decaying plants) and inherent production capacity of the isolates. Among the different types of fungi, A. flavus was favored for cellulase production (Gomathi et al., 2012; Utharalakshmi et al., 2014).

A. terreus (used for oil palm composting) is capable of producing high levels of the three main classes of cellulase (CMCase, $\beta$-glucosidase, and FPase) under the SSF system using agricultural wastes as substrates. Yeast extract was found to be the preferred nitrogen source, with a $\mathrm{pH}$ of 5.5 , and a temperature of $28^{\circ} \mathrm{C}$. Treatment with chemicals such as Tween 80 , magnesium sulfate, and calcium chloride led to a two-fold increase in enzyme production (Shahriarinour et al., 2011). A few reports confirmed that A. terreus can carry out high cellulase 
production under short incubation periods using agricultural wastes (Gao et al., 2008; Jahromi et al., 2011).

Our transcriptional analysis suggested that fermentation systems can have an effect on the expression of enzyme-encoding genes, and increased the level of transcription was achieved using the BF system than using the SmF system. The Aspergillus genus has been characterized as a cellulolytic enzyme producer, and multiple genes encoding cellulase, endoxylanase, and $\beta$-xylosidase have been identified in its isolates (Aro et al., 2005). Several cellulase genes and their expression patterns have been identified through genomic sequencing. Fungal cellulase gene expression and secretion are tightly controlled at the transcriptional level (Stricker et al., 2008). Factors such as isolate efficiency, richness of nutrient broth, $\mathrm{pH}$, oxygen concentration, culture conditions, and fermentation systems play a role in fungi gene expression (Aro et al., 2005; Ward et al., 2006).

In this study, we found that isolate efficiency and fermentation systems affect gene expression. In contrast to the SmF system, in a BF system, fungal species adhere to the substrate. This is a metabolically active process involving various signaling pathways and gene interactions (Osherov and May, 2001). This may explain the higher enzyme activities observed in the BF system, as transcriptional activities are upregulated by specific proteins in BF cultures. The SmF system may be governed by a different set of regulatory mechanisms, and lacks the upregulation in protein activities (Villena et al., 2009). It is possible that SmF cultures work as a homogeneous system, while the BS cultures show heterogeneity in terms of regulatory mechanisms involved in the transcription of cellulolytic enzyme genes (ViniegraGonzález et al., 2003).

mRNA stability is another important factor for the regulation of gene expression. A balance between mRNA synthesis and degradation is not only important for gene expression, but is also vital for cell adaptation (Caddick et al., 2006). Differential EG and $\beta G$ gene expression in $A$. terreus under liquid and solid cultures is regulated by carbon sources and culture conditions (Nazir et al., 2010). The role of cell adhesion in A. niger is an important factor for biofilm development. Therefore, the particular morphogenetic and physiological behaviors of $A$. niger need to be further investigated to establish factors that regulate surfaceadhesion fermentation system (Villena et al., 2009).

\section{Conflicts of interest}

The authors declare no conflict of interest.

\section{ACKNOWLEDGMENTS}

The authors would like to extend their sincere appreciation to the Deanship of Scientific Research at king Saud University for its funding this research group (\#RG-269).

\section{REFERENCES}

Al-Sheikh H, Watson AJ, Lacey GA, Punt PJ, et al. (2004). Endoplasmic reticulum stress leads to the selective transcriptional downregulation of the glucoamylase gene in Aspergillus niger. Mol. Microbiol. 53: 1731-1742. http:// dx.doi.org/10.1111/j.1365-2958.2004.04236.x

Aro N, Pakula T and Penttilä M (2005). Transcriptional regulation of plant cell wall degradation by filamentous fungi. FEMS Microbiol. Rev. 29: 719-739. http://dx.doi.org/10.1016/j.femsre.2004.11.006

Genetics and Molecular Research 15 (4): gmr15048913 
Bak JS (2015). Lignocellulose depolymerization occurs via an environmentally adapted metabolic cascades in the woodrotting basidiomycete Phanerochaete chrysosporium. MicrobiologyOpen 4: 151-166. http://dx.doi.org/10.1002/ $\underline{\mathrm{mbo} 3.228}$

Caddick MX, Jones MG, van Tonder JM, Le Cordier H, et al. (2006). Opposing signals differentially regulate transcript stability in Aspergillus nidulans. Mol. Microbiol. 62: 509-519. http://dx.doi.org/10.1111/j.1365-2958.2006.05383.x

Dutt D and Kumar A (2014). Optimization of cellulase production under solid-state fermentation by Aspergillus flavus (AT-2) and Aspergillus niger (AT-3) and its impact on stickies and ink particle size of sorted office paper. Cellul. Chem. Technol. 48: 285-298.

Gao J, Weng H, Zhu D, Yuan M, et al. (2008). Production and characterization of cellulolytic enzymes from the thermoacidophilic fungal Aspergillus terreus M11 under solid-state cultivation of corn stover. Bioresour. Technol. 99: 7623-7629. http://dx.doi.org/10.1016/j.biortech.2008.02.005

Gehlot P, Purohit DK and Singh SK (2011). Molecular diagnostics of human pathogenic Aspergillus species. Indian J. Biotechnol. 10: 207-211.

Ghigo JM (2003). Are there biofilm-specific physiological pathways beyond a reasonable doubt? Res. Microbiol. 154: 1-8. http://dx.doi.org/10.1016/S0923-2508(02)00012-8

Gomathi D, Muthulakshmi C, Guru KD, Ravikumar G, et al. (2012). Submerged fermentation of wheat bran by Aspergillus flavus for production and characterization of carboxy methyl cellulase. Asian Pac. J. Trop. Biomed. •..: S67-S73. http://dx.doi.org/10.1016/S2221-1691(12)60132-4

Gutiérrez-Correa M and Villena GK (2003). Surface adhesion fermentation: a new fermentation category. Rev. Peru. Biol. 10: 113-124.

Higgins KL, Arnold AE, Miadlikowska J, Sarvate SD, et al. (2007). Phylogenetic relationships, host affinity, and geographic structure of boreal and arctic endophytes from three major plant lineages. Mol. Phylogenet. Evol. 42: 543-555. http://dx.doi.org/10.1016/j.ympev.2006.07.012

Jahromi MF, Liang JB, Rosfarizan M, Goh YM, et al. (2011). Efficiency of rice straw lignocelluloses degradability by Aspergillus terreus ATCC 74135 in solid state fermentation. Afr. J. Biotechnol. 10: 4428-4435.

Kuhad RC, Gupta R and Singh A (2011). Microbial cellulases and their industrial applications. Enzyme Res. $2011: 280696$. http://dx.doi.org/10.4061/2011/280696

Mahmood N, Mariyah A, Ishafaq A, Shahida A, et al. (2014). Molecular expression profile of different cellulolytic enzyme genes in Aspergillus niger in response to UV radiation and chemical mutagenesis. Cellul. Chem. Technol. 48: 529533.

Mahmoud MA, Ali HM, El-Aziz ARM, Al-Othman MR, et al. (2014). Molecular characterization of aflatoxigenic and non-aflatoxigenic Aspergillus flavus isolates collected from corn grains. Genet. Mol. Res. 13: 9352-9370. http:// dx.doi.org/10.4238/2014.November.11.2

Marui J, Kitamoto N, Kato M, Kobayashi T, et al. (2002). Transcriptional activator, AoXlnR, mediates cellulose-inductive expression of the xylanolytic and cellulolytic genes in Aspergillus oryzae. FEBS Lett. 528: 279-282. http://dx.doi. org/10.1016/S0014-5793(02)03328-8

Nazir A, Soni R, Saini HS, Kaur A, et al. (2010). Profiling differential expression of cellulases and metabolite footprints in Aspergillus terreus. Appl. Biochem. Biotechnol. 162: 538-547. http://dx.doi.org/10.1007/s12010-009-8775-9

Ogawa M, Kobayashi T and Koyama Y (2013). ManR, a transcriptional regulator of the b-mannan utilization system, controls the cellulose utilization system in Aspergillus oryzae. Biosci. Biotechnol. Biochem. 77: 426-429. http:// dx.doi.org/10.1271/bbb.120795

Osherov N and May GS (2001). The molecular mechanisms of conidial germination. FEMS Microbiol. Lett. 199: 153-160. http://dx.doi.org/10.1111/j.1574-6968.2001.tb10667.x

Osuna Y, Sandoval J, Saade H, López RG, et al. (2015). Immobilization of Aspergillus niger lipase on chitosan-coated magnetic nanoparticles using two covalent-binding methods. Bioprocess Biosyst. Eng. 38: 1437-1445. http://dx.doi. org/10.1007/s00449-015-1385-8

Parameswaran B, Palkhiwala P, Gaikaiwari R, Nampoothiri K, et al. (2013). Industrial enzymes-present status \& future perspective for India. J. Sci. Ind. Res. 72: 271-286.

Rabinovich ML, Melnik MS and Bolobova AV (2002). Dedicated to the memory of I.V. Berezin and R.V. Feniksova Microbial cellulases. Appl. Biochem. Microbiol. 38: 305-322. http://dx.doi.org/10.1023/A:1016264219885

Raper KB and Fennell DI (1965). Aspergillus section Flavi In: The Genus of Aspergillus (Raper KB and Fennell DI, eds.). Williams \& Wilkins Company, Baltimore, [538].

Reddy GPK, Narasimha G, Kumar KD, Ramanjaneyulu G, et al. (2015). Cellulase production by Aspergillus niger on different natural lignocellulosic substrates. Int. J. Curr. Microbiol. Appl. Sci. 4: 835-845.

Renge V, Khedkar SV and Nandurkar NR (2012). Enzyme synthesis by fermentation method: a review. Sci. Rev. Chem.

Genetics and Molecular Research 15 (4): gmr15048913 
Commun. 2: 585-590.

Saitou N and Nei M (1987). The neighbor-joining method: a new method for reconstructing phylogenetic trees. Mol. Biol. Evol. 4: 406-425.

Shahriarinour M, Wahab MNA, Mohamad R, Mustafa S, et al. (2011). Effect of medium composition and cultural condition on cellulase production by Aspergillus terreus. Afr. J. Biotechnol. 10: 7459-7467.

Shivanna GB and Venkateswaran G (2014). Phytase production by Aspergillus niger CFR 335 and Aspergillus ficuum SGA 01 through submerged and solid-state fermentation. Sci. World J. 2014: 392615. http://dx.doi. org/10.1155/2014/392615

Sørensen A, Lübeck M, Lübeck PS and Ahring BK (2013). Fungal Beta-glucosidases: a bottleneck in industrial use of lignocellulosic materials. Biomolecules 3: 612-631. http://dx.doi.org/10.3390/biom3030612

Sridevi A, Narasimha G, Ramanjaneyulu G, Dileepkumar K, et al. (2015) Saccharification of pretreated sawdust by Aspergillus niger cellulase. 3 Biotech. 5: 883-892.

Stricker AR, Mach RL and de Graaff LH (2008). Regulation of transcription of cellulases- and hemicellulases-encoding genes in Aspergillus niger and Hypocrea jecorina (Trichoderma reesei). Appl. Microbiol. Biotechnol. 78: 211-220. http://dx.doi.org/10.1007/s00253-007-1322-0

Todaka N, Inoue T, Saita K, Ohkuma M, et al. (2010). Phylogenetic analysis of cellulolytic enzyme genes from representative lineages of termites and a related cockroach. PLoS One 5: e8636. http://dx.doi.org/10.1371/journal. pone. 0008636

Utharalakshmi N, Kumar AG and Narendrakumar G (2014). Optimization of cellulase producing Aspergillus flavus SB4 by solid state fermentation using rice bran. J. Pure Appl. Microbiol. 8: 713-719.

Villena GK, Fujikawa T, Tsuyumu S and Gutiérrez-Correa M (2009). Differential gene expression of some lignocellulolytic enzymes in Aspergillus niger biofilms. Rev. Peru. Biol. 15: 97-102.

Villena GK and Gutiérrez-Correa M (2006). Production of cellulase by Aspergillus niger biofilms developed on polyester cloth. Lett. Appl. Microbiol. 43: 262-268. http://dx.doi.org/10.1111/j.1472-765X.2006.01960.x

Viniegra-González G, Favela-Torres E, Aguilar CN, Rómero-Gomeza S, et al. (2003). Advantages of fungal enzyme production in solid state over liquid fermentation systems. Biochem. Eng. J. 13: 157-167. http://dx.doi.org/10.1016/ $\underline{\text { S1369-703X(02)00128-6 }}$

Ward OP, Qin WM, Dhanjoon J, Ye J, et al. (2006). Physiology and biotechnology of Aspergillus. Adv. Appl. Microbiol. 58: 1-75. http://dx.doi.org/10.1016/S0065-2164(05)58001-8

Watanabe H and Tokuda G (2001). Animal cellulases. Cell. Mol. Life Sci. 58: 1167-1178. http://dx.doi.org/10.1007/ PL00000931

Zhou M, Huang ZQ, Zhou B, Luo YL, et al. (2015). Construction and expression of two-copy engineered yeast of feruloyl esterase. Electron. J. Biotechnol. 18: 338-342. http://dx.doi.org/10.1016/j.ejbt.2015.06.004

Genetics and Molecular Research 15 (4): gmr15048913 